\title{
DEFINISI PATEN SERTA HAK APA YANG HARUS DIHINDARI SEBELUM PERMINTAAN PATEN DI AJUKAN
}

EGA YULIANI

155100023

Fakultas Komputer, 448757176

Egayuliani.student@umitra.ac.id

\begin{abstract}
Hak Kekayaan Intelektual (HKI) saat ini menjadi isu sangat penting bagi Negara-negara maju dan Negara-negara berkembang seperti Indonesia. Sistem HKI digunakan oleh Negara-negara maju sebagai sarana untuk mendorong pertumbuhan ekonomi dan kesejahteraan social.

Perkembangan ilmu pengetahuan khususnya teknologi telah menjadi tonggak utama penyempurnaan hidup manusia, dari yang sederhana tradisional menjadi modern dan sangat kompleks. Dengan berkembangnya teknologi industri banyak pekerjaan manusia mulai dari yang sangat sederhana, seperti mencuci pakaian, sampai pekerjaan seorang dokter mengoperasi jantung dapat dialihkan kepada teknologi untuk mengganti tenaga manusia untuk pekerjaan yang sangat sulit. Contoh lain, misalnya teknologi transportasi telah memperpendek jarak dalam waktu. Kalau dulu colombus membutuhkan waktu sampai berbulan-bulan mengarungi lautan untuk sampai ke benua Amerika. Sekarang, untuk pindah dari satu benua ke benua lain hanya
\end{abstract}

Kata Kunci : Paten dan HAKI 


\section{A. INTRODUCTION}

Hak Kekayaan Intelektual (HKI) saat ini menjadi isu sangat penting bagi Negara-negara maju dan Negara-negara berkembang seperti Indonesia. Sistem HKI digunakan oleh Negara-negara maju sebagai sarana untuk mendorong pertumbuhan ekonomi dan kesejahteraan social. Perkembangan ilmu pengetahuan khususnya teknologi telah menjadi tonggak utama penyempurnaan hidup manusia, dari yang sederhana tradisional menjadi modern dan sangat kompleks. Dengan berkembangnya teknologi industri banyak pekerjaan manusia mulai dari yang sangat sederhana, seperti mencuci pakaian, sampai pekerjaan seorang dokter mengoperasi jantung dapat dialihkan kepada teknologi untuk mengganti tenaga manusia untuk pekerjaan yang sangat sulit. Contoh lain, misalnya teknologi transportasi telah memperpendek jarak dalam waktu. Kalau dulu colombus membutuhkan waktu sampai berbulan-bulan mengarungi lautan untuk sampai ke benua Amerika. Sekarang, untuk pindah dari satu benua ke benua lain hanya

$\begin{array}{lll}\text { 2.IstilahDan } & \text { Konsep } & \text { Dasar } \\ \text { Perlindungan } & & \text { Paten }\end{array}$

Dalam kamus bahasa inggris dapat diketahui bahwa patent adalah lawan kata latent. Kata paten berasal dari bahasa inggris yang berakar pada bahasa latin patere yang artinya membuka diri (untuk pemeriksaan public). Konsep dasar paten adalah mendorong inventor (penemu) untuk membuka ide atas temuannya secara detail demi kemajuan masyarakat (dan yang nantinya akan ditiru setelah masa perlindungannya berlalu atau dipergunakan untuk kepentingan dan kebutuhan manusia dalam meningkatkan taraf hidupnya. Dan, sebagai gantinya, ia mendapat hak eksklusif dari pemerintah yang 
berwenang dalam hal ini Dirjen

HKI untuk melaksanakan paten yang dimilikinya dan melarang pihak lain mengeksploitasinya tanpa ijin selama periode waktu tertentu, dan dilindungi oleh hokum. Dengan alasan ini dapat dipahami bahwa system pemberian hak paten bukan dianggap sebagai hak monopoli Mengapa undang-undang paten Indonesia menggunakan kata invensi dan bukan temuan? Kata menemukan dalam bahasa Indonesia mempunyai arti yang sangat luas. Kita bias menemukan apa saja, dimana saja dan kapan saja. Tetapi to invent walau berarti menemukan juga, tetapi mempunyai nuansa berbeda, disamping itu to invent dan to discovery mempunyai dasar pemahaman yang berbeda juga.

3. Sejarah Paten di Indonesia Indonesia mulai mengenal hak paten sejak jaman penjajahan Belanda, yaitu ketika berlakunya Octrooiwet 1910 S. No. 33 yis S/11-33, S 22-54 yang berlaku mulai 1 Juli 1912. Setelah Indonesia merdeka, pemerintah melihat bahwa ketentuan itu tidak sesuai lagi dengan nilai-nilai kemerdekaan Indonesia. Hal ini disebabkan undang-undang itu mengharuskan permohonan Octrooi diajukan ke Belanda.

\section{Definisi dan Dasar Hukum Paten} Apakah paten itu? Undang-undang tidak member definisi yang tegas tentang paten. Black's Law Dictionary member definisi tentang paten sebagai berikut: a. Penganugerahan preville, pemilikan dan otoritas oleh pemerintah kepada satu atau beberapa orang. b. Penganugerahan terhadap penemu dari pemerintah, mengumumkan dan melindungi hak ekseklusif untuk membuat, menggunakan dan menjual penemuannya untuk jangka waktu tertentu.

Kamus Bahasa Indonesia memberikan definisi paten adalah hak yang diberikan pemerintah kepada seseorang atas suatu 
penemuan untuk digunakan sendiri dan melindunginya dari peniruan (pembajakan).

Di Indonesia paten diatur dalam undang-undang No. 14 tahun 2001, dan secara internasional dasar hokum paten adalah: Paris Convention, Paten Cooperation Treaty (PCT), Eropean Patent Convention (EPC) dan TRIPs. Undang-undang No. 14 tahun 2001 tentang paten tidak mendefinisikan secara jelas tentang apa itu paten, tetapi pasal 1 ayat 1 memberi definisi tentang hak paten sebagai berikut:

"Paten adalah hak eksklusif yang diberikan oleh Negara kepada inventor atas hasil invensinya di bidang teknologi, yang untuk waktu tertentu melaksanakan endiri invensinya tersebut atau memberikan persetujuannya kepada pihak lain untuk melaksanakannya".

5. Ruang Lingkup Paten Di Indonesia syarat untuk suatu invensi yang dapat dipatenkan adalah a. Baru atau novelty; baru berarti belum pernah diungkapkan sebelumnya. Teknologi dalam invensi tidak sama dengan teknologi yang sudah pernah terungkap sebelumnya. Untuk memastikan bahwa teknologi yang diteliti belum dipatenkan oleh pihak lain dan layak untuk dipatenkan, inventor sebelum memohon pendaftaran dapat melakukan penelususran dokumen paten, baik melalui internet atai library.

b. Mengandung langkah inventif artinya; belum dapat diduga sebelumnya oleh pakar dibidangnya.

c. Dapat diterapkan dalam dunia industry artinya; bukanteori semata. Obyeknya baik paten proses atau paten produk dan alat akan diproduks dalam jumlah besar dan diperjualbelikan, serta haknya dapat dialihkan ke dunia bisnis melalui perjanjian lisensi, atau yang lain.

6. Sistem Pendaftaran Paten Ada dua (2) system pendaftaran 
paten,

yaitu:

a. Sistem first to file adalah suatu system yang memberikan hak paten bagi mereka yang mendaftar pertama atas invensi baru sesuai dengan persyaratan.

b. Sistem first to invent adalah suatu system yang memberikan hak paten bagi mereka yang menemukan inovasi pertama kali sesuai dengan persyaratan yang telah

ditentukan.

Dokumen-dokumen yang diperlukan untuk pendaftaran permohonan paten adalah sebagai berikut:

a. Formulir yang telah diisi.

b. Spesifikasi permohonan paten

3rangkap.

c. Surat kuasa, jika diajukan melalui kuasa hokum.

d. Surat pernyataan untuk diberi paten.

7. Hal-hal Dihindari Sebelum Mengajukan Paten Yang harus dihindari sebelum permintaan paten diajukan adalah pengungkapan atau mempublikasikan secara umum hasil penelitian atau penemuan dalam jangka waktu 6 (enam) bulan sebelum permintaan paten diajukan. Pengugkapan suatu hasil penelitian atau penemuan dapat terjadi dalam 3cara: a. Melalui penguraian teknik dengan tulisa yang dipublikasikan. b. Melalui penguraian produk dan atau cara penggunanya di depan umum

c. Melalui pameran produk, dapat berupa suatu pameran internasional atau nasional di Indonesia atau di luar negeri yang resmi atau diakui sebagai resmi.

\section{B. CONCLUSION}

Hak Kekayaan Intelektual (HKI) saat ini menjadi isu sangat penting bagi Negara-negara maju dan Negara-negara berkembang seperti Indonesia. Sistem HKI digunakan oleh Negara-negara maju sebagai sarana untuk mendorong pertumbuhan ekonomi dan kesejahteraan social.

Perkembangan ilmu 
pengetahuan khususnya teknologi

telah menjadi tonggak utama penyempurnaan hidup manusia, dari yang sederhana tradisional menjadi modern dan sangat kompleks. Dengan berkembangnya teknologi industri banyak pekerjaan manusia mulai dari yang sangat sederhana, seperti mencuci pakaian, sampai pekerjaan seorang dokter mengoperasi jantung dapat dialihkan kepada teknologi untuk mengganti tenaga manusia untuk pekerjaan yang sangat sulit. Contoh lain, misalnya teknologi transportasi telah memperpendek jarak dalam waktu. Kalau dulu colombus membutuhkan waktu sampai berbulanbulan mengarungi lautan untuk sampai ke benua Amerika. Sekarang, untuk pindah dari satu benua ke benua lain hanya.

Sistem Pendaftaran Paten Ada dua (2) system pendaftaran paten, yaitu: a. Sistem first to file adalah suatu system yang memberikan hak paten bagi mereka yang mendaftar pertama atas invensi baru sesuai dengan persyaratan. b. Sistem first to invent adalah suatu system yang memberikan hak paten bagi mereka yang menemukan inovasi pertama kali sesuai dengan persyaratan yang telah ditentukan.

Dokumen-dokumen yang diperlukan untuk pendaftaran permohonan paten adalah sebagai berikut:

a. Formulir yang telah diisi.

b. Spesifikasi permohonan paten: 3 rangkap.

c. Surat kuasa, jika diajukan melalui kuasa hokum.

d. Surat pernyataan untuk diberi paten.

\section{ACKNOWLEDGEMENT University Of Indonesia University Of Mitra Indonesia Telkom University University Of Mellbourne Saitama University}

\section{REFERENCE(Based ISO 690 )}


Lampung Province," In Prosiding International Conference On Information Technology And Business (Icitb), 2018, Pp. 181-187.

[2] A. S. Putra, O. M. Febriani, And B. Bachry, "Implementasi Genetic Fuzzy System Untuk Mengidentifikasi Hasil Curian Kendaraan Bermotor Di Polda Lampung," J. Sist. Inf. Dan Manaj. Basis Data, Vol. 1, No. 1, Pp. 21-30, 2018.

[3] O. M. Febriani And A. S. Putra, "Sistem Informasi Monitoring Inventori Barang Pada Balai Riset Standardisasi Industri Bandar Lampung," J. Inform., Vol. 13, No. 1, Pp. 90-98, 2014.

[4] Putra, Arie Setya. "2018 Artikel Struktur Data, Audit Dan Jaringan Komputer." (2018).

[5] Putra, A. S. (2018, July 17). Paperplain Fundamental Create Application With Borland Delphi 7.0 University Of Mitra Indonesia. Retrieved From Osf.Io/Pbrn9.

\section{E. REFERENCE(Based APA )}

Putra, A. S., Aryanti, D. R., \& Hartati, I. (2018, November). Metode SAW (Simple Additive Weighting) sebagai Sistem Pendukung Keputusan Guru Berprestasi (Studi Kasus: SMK Global
Surya). In Prosiding Seminar Nasional Darmajaya (Vol. 1, No. 1, pp. 85-97).

Sari, D. P., Febriani, O. M., \& Putra, A. S. (2018, November). Perancangan Sistem Informasi SDM Berprestasi pada SD Global Surya. In Prosiding Seminar Nasional Darmajaya (Vol. 1, No. 1, pp. 289-294).

Putra, A. S. (2018). Paperplain: Execution Fundamental Create Application With Borland Delphi 7.0 University Of Mitra Indonesia.

Putra, A. S., Sukri, H., \& Zuhri, K. Sistem Monitoring Realtime Jaringan Irigasi Desa (JIDES) Dengan Konsep Jaringan Sensor Nirkabel. IJEIS (Indonesian Journal of Electronics and Instrumentation Systems), 8(2), 221232.

Darmawan, A., Yuliawati, D., Marcella, O., \& Firmandala, R. (2016). Sistem Absensi dan Pelaporan Berbasis Fingerprint dan SMS Gateway. EXPLORE, 7(1).

Febriani, O. M., Wahyuni, T., \& Yusuf, S. (2017). DESIGN OF WEBSITE-BASED INFORMATION SYSTEM FOR EDOCUMENT ADMINISTRASI IN THE COMMUNITY SERVICE UNIT (A Case Study at Rajabasa District). INTERNATIONAL JOURNAL OF COMPUTERS \& TECHNOLOGY, 16(7), 7010-7020.

Febriani, O. M., \& Wahyuni, T. (2017, October). PERANCANGAN SISTEM E-DOCUMENT ADMINISTRASI LOGBOOK PENELITIAN PADA 
UNIT LAYANAN DI BANDAR LAMPUNG. In Prosiding Seminar Nasional Darmajaya (Vol. 1, No. 1, pp. 187-194).

Febriani, O. M., \& Permadi, A. B. (2017). Implementasi Sistem Aplikasi Data Bimbingan dan Pelanggaran Siswa pada Sekolah Menengah Atas di Lampung Tengah dengan Metode Analisis dan Desain Sistem Terdistribusi (SSAD). EXPERT, 7(1).

Febriani, O. M., \& Ambarwati, L. (2015). PERANCANGAN APLIKASI PENGOLAHAN DATA PENJUALAN UKM KELANTING KHAS TELO DESA SIDOHARJO KECAMATAN JATI AGUNG KABUPATEN LAMPUNG SELATAN. Jurnal Teknologi Informasi dan Bisnis Pengabdian Masyarakat Darmajaya, 1(1), 77-95.

Febriani, O. M. (2015). Rancang Bangun Aplikasi Ecommercemenggunakan Freewebstore pada UKM Kelanting di Desa Sidoharjo Lampung Selatan. Prosiding Sembistek 2014, 1(02), 446-458. 